\title{
Will China's Development lead to Mexico's Underdevelopment?
}

\author{
Kathleen C. Schwartzman \\ University of Arizona \\ kes@email.arizona.edu
}

\begin{abstract}
China has become an important global actor in the arenas of production, trade, and foreign investment. In 1948, China contributed slightly less than 1 percent to global exports; by 2013, it had grown to almost 12 percent. Has China's vertiginous trade growth come at the expense of other exporters or does it represent an expansion of new consumer markets? For policy makers in the so-called "emerging markets," this is most relevant since many have adopted the exportled model as their engine of development. The goal of this article is to add to the current literature on the effect of China's growth on Mexico. Combining elements of world-systems, race-to-the-bottom, and global commodity chain frameworks, I analyze the consequences of China's export growth in garlic. The evidence strongly suggests that China's entrance into this global market has had deleterious consequences for Mexico's production and exports.
\end{abstract}

Keywords Globalization, Underdevelopment, South-South Competition, Mexico, China, Garlic

Mexico has faced many economic challenges since gaining independence from Spain. China's participation in global economic exchanges poses a new one. In 1948, China contributed slightly less than 1 percent to global exports; by 2013, it had grown to almost 12 percent (Figure 1). In 1979, China began to open its economy with tariff reductions and launched its own export upsurge. Two inflection points stand out ${ }^{1}$ : one in 1983 and another in 2002 following China's adherence to the WTO.

China's WTO commitments included reducing its average tariff rate to 10 percent by 2005 , and eliminating import quotas, licenses, designated trading practices, and other non-tariff barriers. China agreed to limit domestic agricultural subsidies to 8.5 percent of the value of production (below the 10 percent limit allowed for developing countries under the WTO Agreement on Agriculture), and to eliminate all agricultural export subsidies prohibited by the WTO, including grants and tax breaks linked to exporting. Most importantly, it would eliminate

${ }^{1}$ WTO (2010) Merchandise includes raw materials and agricultural products; everything except services.

This work is licensed under a Creative Commons Attribution 4.0 United States License. Journal of World-Systems Research, Volume 21, Number 1, Pages 106-123, ISSN 1076-156X 
constraints on foreign investment (e.g. technology transfer or local content requirements), and it would protect investors' intellectual property rights (Rumbaugh and Blancher 2004).

In exchange, China's adherence to the WTO expanded its ability to export to previously closed, limited, or high-tariff markets. China "joined" global commodity chains by becoming the host country for outsourcing. Foreign corporate actors initiated China's integration into global networks. Some were very large (Foxconn); some were small (McGill--producer of paper punches); some were retailers such as Wal-Mart and Crate and Barrel, while others were wholesalers.

Figure 1. Shares of World Merchandise Exports: US, China, \& Mexico ${ }^{2}$

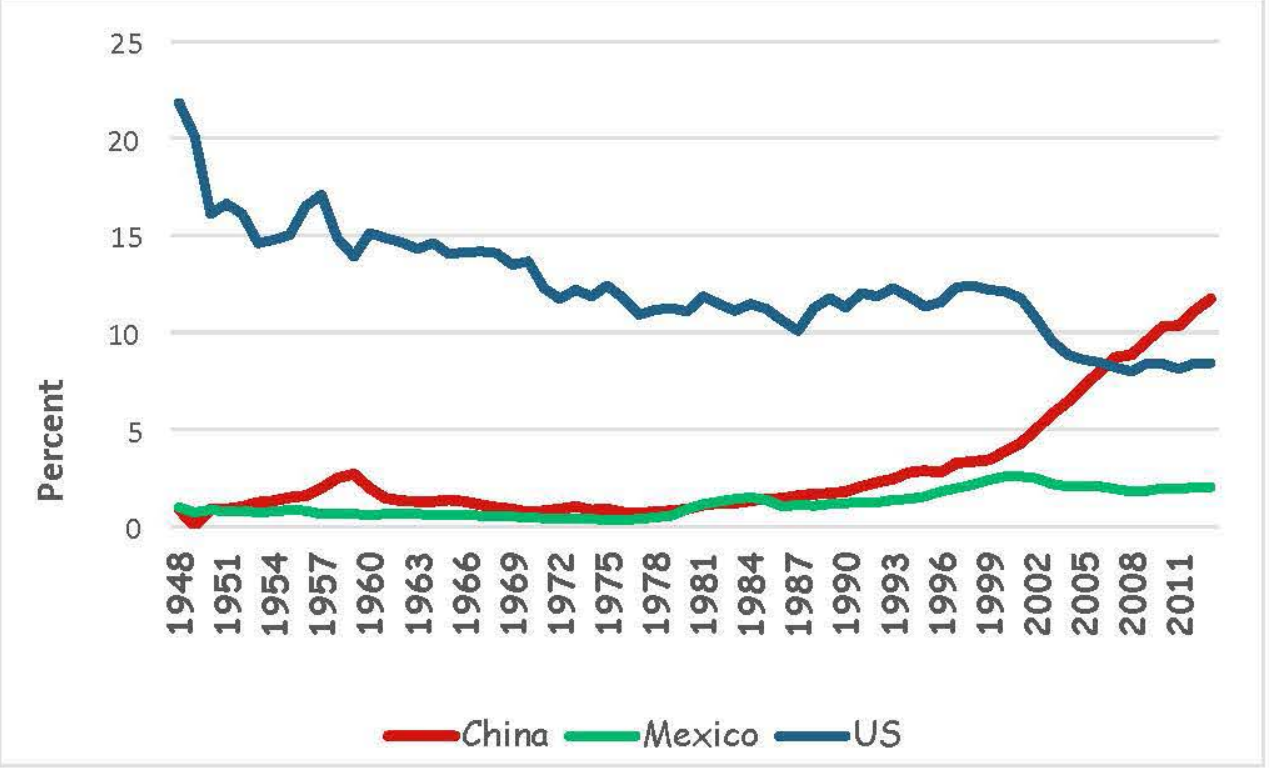

For policy makers in other emerging markets (also known as developing or lesser developed countries), it is important to ask if China's vertiginous trade growth has come at the expense of other exporters, or if it represented an expansion of new consumer markets. This question is most relevant for those nations that have adopted the export-led model as their engine of development. The goal of this article is to add to the literature on the effect of China's growth on other nations and on Latin America. Combining elements of world-system, race-to-the-bottom, and global commodity chain frameworks, I analyze the consequences of China's export growth in garlic.

\section{Theoretical Significance}

We are in the midst of a global "race to the bottom": in labor standards, wages, and environmental integrity. The displacement of Mexico from the U.S. garlic market is one small example of this global race. It exemplifies Wallerstein's initial notion that production chains are fluid, and nodes can be substituted on the basis of geography, labor regime, technology, or

\footnotetext{
${ }^{2}$ Unless otherwise indicated, graphs and tables are authors' calculations based on data from FAO, WTO, U.S. Department of Commerce, Bureau of the Census, Foreign Trade Division, and Mexico, Secretary of Agriculture (SAGARPA).
} 
political regime. In contemporary discussions, race-to-the-bottom has provided the conceptual framework for analyzing the effect of globalization on national labor regimes (Chan and Ross 2003) and environment.

In the relay race, producers and distributors move from one developing nation to another. It unleashes a South-South competition. Although host governments do not initiate the race, they become complicit in bidding wars because they, as much as foreign investors, want to maintain their "competitive advantages" of, for instance, cheap labor, lax working conditions, and lenient environmental regulations (Hough 2012). They are responding to firms from the developed world searching for lower production costs. Despite the "hospitality" host governments extend to investors, they often end up worse off. Given a global consumer market that is relatively inelastic in the short-run, one country's gain is likely to be another's loss; not every nation can be a net exporter.

The fluidity of global trade, subcontracting, as well as foreign direct investment are not simply universal processes of "globalization." This race-to-the-bottom is best understood when embedded in World-systems theory, which offers the analytical leverage to understand the "why" and the "when" of such races. Scholars have argued that U.S. firms, in an attempt to maintain their economic niche and profit levels, began transforming production: partitioning production into commodity chains and inserting more offshore maquiladoras (more countries) into the final product. Over time this led to a perpetual race-to-the bottom. Specifically, worldsystems theory allows us to link the continuous search for lower production costs - the race-tothe-bottom - with the U.S. profit crises and hegemonic slide (B-phase). The current global flows follow a U.S. hegemonic slide that began two decades earlier and was precipitated by stagnating rates of capital accumulation and the rising cost of socially-oriented state intervention and regulation (Harvey 2005). This hegemonic decline is reflected in multiple indicators of global economic dominance (Economist 2013; Harvey 2007; Thurow 1992; Bowles, Gordon, and Weisskopy 1983). Commentators are divided on whether or not this represents a transient decline or a real economic contraction characteristic of the B-phase of the Kondratieff cycle. Putting aside that debate, we can at least say that capital mobility is fundamental for the reproduction of capital. The race-to-the-bottom accomplishes this with a constant compression of production time and production space (Bonanno and Cavalcanti 2011).

The early B-phase gave way to North-South (N-S) competition. As the U.S. economy contracted and profit rates fell, firms sought cheaper labor, moving parts of the production process to Mexico. The Charles E. Gillman Company, an early mover, recognized an opportunity to become more competitive in the wire and cable industry by locating part of its production in Mexico in 1970. The Mexican 'division' reduced operating costs, and allowed the company "to pass on substantial savings to our customers" (Gillman). Together, the race-to-the-bottom and world-systems theory frameworks direct our attention to the N-S competition (United States and Mexico), which was both prior to, and responsible for unleashing the South-South competition (Mexico and China).

World-systems theory and race-to-the-bottom provide theoretical foundations for the study of Global Commodity Chains (GCC). The earlier concept of Hopkins and Wallerstein (1977) has been extended and modified (Gereffi and Korzeniewicz 1994; Gereffi et al. 2001). GCC describes a production process that crosses national boundaries, utilizes diverse forms of labor control, and does so under the umbrella of interconnected firms. Any of the actors along the chain may subcontract or allocate tasks to countries that possess advantages--typically natural resources, cheap labor, political stability, or environmental conveniences. GCC is concerned 
with understanding how commodities are produced: identifying sets of inter-firm networks which connect manufacturers, suppliers and subcontractors in global industries to each other, and ultimately to international markets (Bair 2005: 156). The goal is to identify where, how, and by whom value is created and distributed. While world-systems theory and race-to-the-bottom identify the root causes of these chains, GCC investigates their organizational forms. The GCC that we observe today would have been impossible without the rapid rise of new technologies facilitating the mobility of production components (Castells 1989). Together, these interconnected frameworks offer analytical leverage to speculate on the fate of peripheral or semi-peripheral nations that are highly dependent upon core nations undergoing a contraction or hegemonic slide (Frank 1969).

In the first section of this paper, I review some of the research on the "China effect" for both developed and underdeveloped countries. Then I summarize some of the research on the "China effect" for Latin American in general, and for Mexico in particular. Finally, I describe my analysis of the garlic industry. Unlike the conclusions that posit 'no negative effect' for developing countries, I conclude that in this case, China's gain was Mexico's loss; the U.S. hegemonic slide had a negative consequence for its Mexican satellite.

\section{The China Factor in the World Economy}

Most countries have increased their imports from China, but has it been at the expense of other exporters? And are all exporting countries losing their foreign markets? Using trade data from 1995-2010, Husted and Nishioka (2013: 567) test the impact of China's trade growth on 93 other exporters $^{3}$. They are particularly interested in distinguishing the impact of China's gains on developed from those on developing countries. They find that developing countries have not seen their share diminished, but developed countries, namely Japan and the United States, have. Within their sample of 91 importers, the United States lost export market shares in all but eighteen countries while China gained in all.

Subdivided into time periods, they find that from 1995 to 2000 , China's share growth was moderate; from 2000 to 2005 , China's share growth was greater and accompanied by a market share loss for the United States. From 2005 to 2010, China continued to increase its market share. In analyzing China's increased shares, they partition out the expansion in the variety of new commodities exported (extensive margin) from an increase in existing commodities (intensive margin). Their findings do not support the conclusions of Broda and Weinstein who find that about 30 percent of U.S. import growth was of the extensive type; but are in line with Amiti and Freund (2010) (quoted in Husted and Nishioka 2013) who find that most of the export growth from 1997 to 2005 was of already existing commodities (2013:571) ${ }^{4}$. In both cases, outsourcing and the fragmentation of production into Global Commodity Chains are important contributors to market gains. Between 2003 and 2005, Chinese joint ventures and affiliates accounted for 75 percent of the increase in China's trade (Manova and Zhang 2009, quoted in Husted and Nishioka 2013: 576).

\footnotetext{
${ }^{3}$ Their sample accounted for $76.8 \%$ of total world imports.

${ }^{4}$ Husted and Nishioka (2013) provide an extensive literature review.
} 


\section{The China Factor in Latin American Economies}

This literature addresses two questions: what is China's effect on Latin America's export markets; and what is its effect on Latin America's domestic markets? China's export growth can affect Latin America by taking over some or all of its third-country market shares, or by exerting downward pressure on global prices. Secondly, China's growth can affect Latin American producers by competing in their own domestic markets.

Gallagher and Porzecanski (2008) use the UN Commodity Trade Statistics Database (UN Comtrade) to investigate whether China's rise as a global exporter affected the ability of Latin American and Caribbean countries (LAC) to compete in world export markets. They conclude that China and LAC are not competitors on the world market because they have dissimilar export profiles. LAC countries export primarily raw materials and primary goods (2008:186). I describe their findings about Mexico in the next section.

China and Latin America may not be competitors but the trade relationships between them are asymmetrical. In 1993, LAC had a trade surplus with China; by 2005 it had a deficit. The Chinese market is important for the Latin American exports of raw materials and primary products such as grains, beef, and copper (Gallagher and Porzecanski 2008: 189). At the same time, LAC import high-value added manufacturing goods from China. China is critical for LAC trade, but the inverse is not the case. In 2005, Latin America received only 3 percent of all of China's exports and accounted for only 3.8 percent of China's imports. By 2009 China was Brazil's major trading partner. Brazil exports low-value-added goods and primary products to China: more than 75 percent is comprised of iron, soybeans, and oil. In contrast, Brazil imports value-added and high technology goods from China. Perpetuating this disadvantageous raw material -value-added exchange is the fact that China protects some of its commodities in its home market. The level of trade protection varies with the degree of processing. Jenkins, Peters, and Moreira cite the case of Brazilian soybean exports in 2005: soybeans accounted for 28 percent of exports to China in 2005 while processed soybean oil accounted for only 2 percent (2008: 238). In this way, China's import and export growth contribute to the persistent current account deficits of LAC and put them further behind in the race to 'catch up' to other developing countries in establishing manufacturing capabilities.

Latin American producers have additional concerns about their own domestic markets. From 1995 to 2005, imports from China rose from 1.8 to 5.5 percent of total LAC imports (Jenkins et al. 2008: 239). Again we can ask if these imports represent new commodities previously not available or competition with domestically produced ones. Antidumping cases against China register the fear of LAC producers that domestic markets are threatened by Chinese imports. In 2008, China was the target of 33 percent of Brazil's ongoing antidumping cases, 50 percent of Peru's, and 100 percent of Colombia's (Weik 2013). Brazilian steel producers were alarmed by China's decision to eliminate its export taxes (effective December 1, 2008 ) on cold-rolled, galvanized, and high value-added steel products. From January to August 2008, Chinese exports of steel to Latin America grew 36 percent against 17 percent to the rest of the world. Of additional concern for the Brazilian steel industry was China's plan to scrap export taxes on hot-rolled steel, section steel, and steel rods and wires (Brasilians 2008). Brazilian industry representatives claimed that subsidization in China has likely harmed them in both the domestic and export markets. 


\section{The China Factor in the Mexican Economy}

Here I consider four questions. Did China displace Mexico from: 1) global markets, 2) the U.S. market, 3) its own domestic market, and 4) its garlic markets in all of the above? In Husted and Nishioka's analysis, Mexico did not fare so badly. Their analysis assumes that total market shares remain constant overtime. They analyze the total overtime market-share changes to determine the weight of the competition component (the intensive margin). I have extracted several data points from their individual country analysis (Table 1). They conclude that Mexico, (in their "developing countries" subsample), did not lose significant global market shares to China between 1995 and 2010. When subdivided into three time periods however, Mexico shows positive growth during the first period and a slight loss during the second. The 2000-2005 period spans the time when China joined the WTO and firms left Mexico for the new destination. Transferring foreign direct investment from Mexico to China explains some of this change. For example, \$514 million was diverted from the Hi-tech hub of Guadalajara alone. Overall, however, they calculate an insignificant effect (.847), concluding, "Mexico's export shares hardly changed over the period even as China's shares rose across the board" (Husted and Nishioka 2013: 580).

Table 1. Changes in Global Export Market Share

\begin{tabular}{lrr}
\hline & Mexico & United States \\
\hline & & \\
$1995-2000$ & 1.154 & 1.823 \\
$2000-2005$ & -.447 & -5.406 \\
$2005-2010$ & .139 & -.706 \\
Total change $1995-2010$ & .847 & -4.290
\end{tabular}

Source: Husted and Nishioka (2013:575, 577, Tables 3 and 4)

Other studies, while concluding that developing countries generally did not suffer material damage, identify Mexico as an outlier. In comparing Brazil and Mexico, Jenkins et al. conclude that Brazil has fared better as a major exporter of primary commodities to China, while Mexico has been negatively affected by Chinese competition in export markets, particularly the United States (2008: 237). "There is near unanimous consensus that Mexico is losing competitiveness and foreign investment to China" (Gallagher and Porzecanski 2008: 186, 192). This is because Mexico's comparative advantage and export profile are similar to that of postWTO China. Many judge the losses to be greatest in low-tech, labor-intensive goods (such as textiles and electronics). After 2005, China gained access to markets (such as the EU and the United States) from which it had been restricted under the 1995 Agreement on

Textiles and Clothing (ATC). It significantly increased its clothing and textile exports. As others have documented, China began exporting textiles and lightly manufactured goods, but subsequently diversified to include sophisticated electronics, machinery, and transportation goods. The latter three contributed 17 percent to China's exported value in 1993 and rose to 41 
percent in 2003 (Rumbauth and Blanche 2004). Table 2 highlights China's shift in commodity composition and in world shares.

Table 2. China's Export Profile

\begin{tabular}{lcc|cc}
\hline & $\begin{array}{c}\text { Composition of Chinese Exports } \\
1995\end{array}$ & 2010 & \multicolumn{2}{c}{ China's Share in World Exports } \\
& 4.5 & 2.0 & 3.4 & 2010 \\
\hline $\begin{array}{c}\text { Food and live } \\
\text { animals }\end{array}$ & 23.2 & 50.8 & 3.1 & 5.0 \\
$\begin{array}{c}\text { Machinery and } \\
\text { transport } \\
\text { equipment }\end{array}$ & & & & 19.0 \\
\hline
\end{tabular}

As is evident in Figure 1 above, Mexico did not fare well as China increased its global share; but Mexico's loss in the "global market" may actually underestimate the real loss. Since Mexico has a dependent relationship with the United States, the displacement in the U.S. market matters significantly more than its displacement in the global market. This dependency is reflected in the trade, foreign direct investment, and capital flows between the two countries. All nations engage in these flows, but dependency is distinct from simple exchanges because of Mexico's asymmetrical trade with the United States. In 2012, 78 percent of Mexico's exports were destined for the United States whereas only 14 percent of U.S. exports were destined for Mexico. In other words, Mexico counts on the United States to purchase a bulk of its exports (monopsony), but the United States does not count on Mexico. Likewise, half of Mexico's imports come from the United States. As many have pointed out, these flows represent Mexico's maquiladora participation in global commodity chains. Although, the United States has increased both its volume and percentage of trade flows with Mexico, the United States is far from having a trading partner concentration with Mexico. For instance, Mexico's share of U.S. trade is minor (Table 3).

Table 3. U.S.-Mexico Trade

\begin{tabular}{lll|ll}
\hline & \multicolumn{2}{c|}{$\%$ of Country Exports } & \multicolumn{2}{c}{ \% of Country Imports } \\
\cline { 2 - 5 } & Mexico to & U.S. to Mexico & To Mexico from & To U.S. from \\
U.S. & 60.4 & 4.72 & 66.6 & 4.66 \\
& 69.3 & 5.28 & 66.1 & $6.24(1991)$ \\
1985 & 91 & 10.38 & 74.1 & 9.38 \\
1990 & 80.07 & 12.79 & 48.24 & 11.79 \\
2000 & 77.70 & 14.0 & 50.08 & 12.0 \\
2010 & & & & \\
2012 & 69.71 & & 76.44 & \\
$1930-1960$ & & & 64.00 & \\
$\begin{array}{l}\text { average } \\
1960-1980\end{array}$ & 64.55 & & & \\
average & & & & \\
\hline
\end{tabular}


Notwithstanding geographic proximity and NAFTA, the highly touted free trade agreement, total U.S. import value from China surpassed Mexico in 2003. By 2010, U.S. imports from China were one and a half times the value of those from Mexico (Figure 2). Exacerbating the asymmetric relationship, the United States continued to export significantly more to Mexico than it did to China (Figure 3).

Figure 2. U.S. Imports from Mexico and China

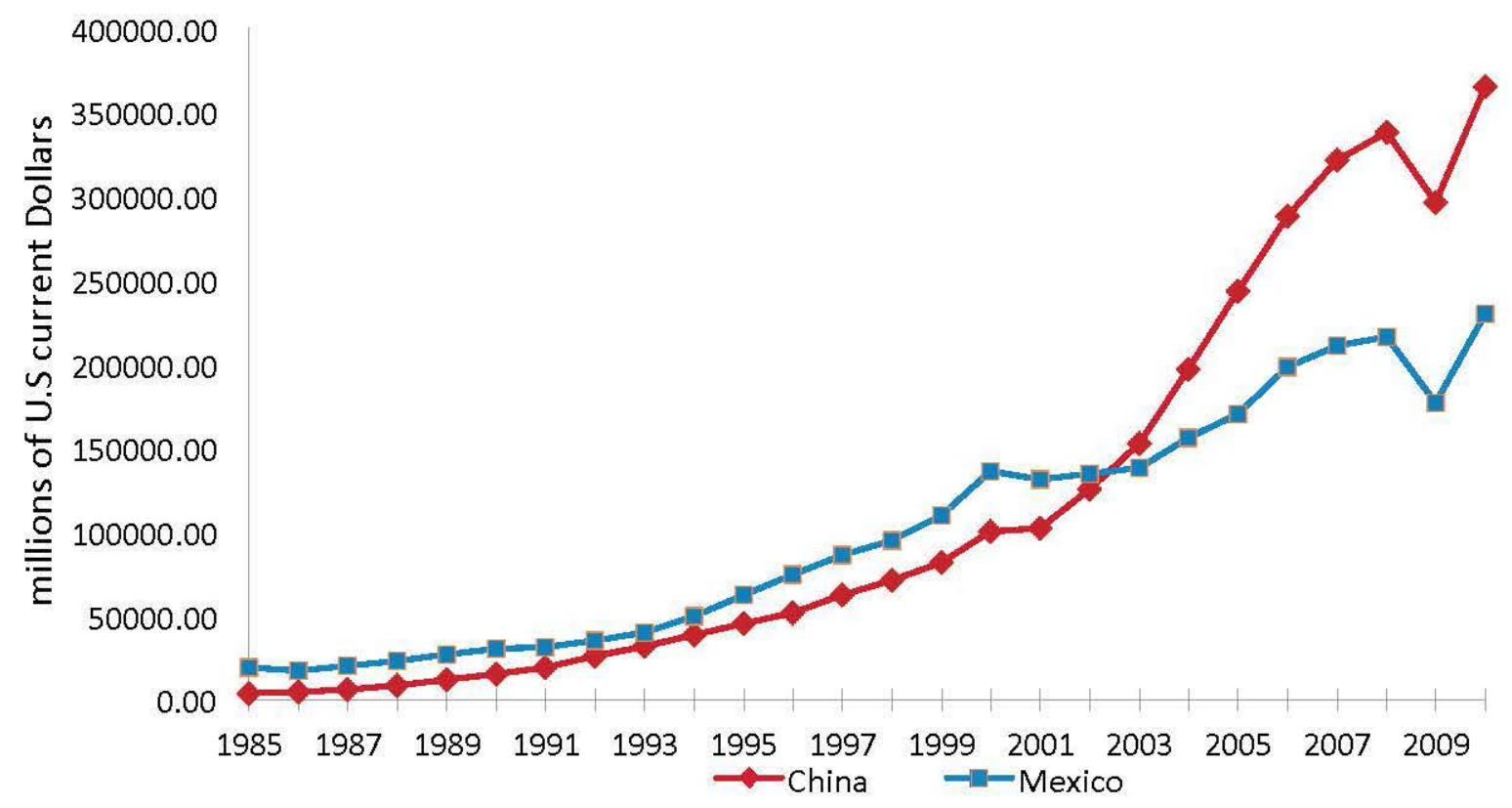

Figure 3. U.S. Exports to Mexico and China

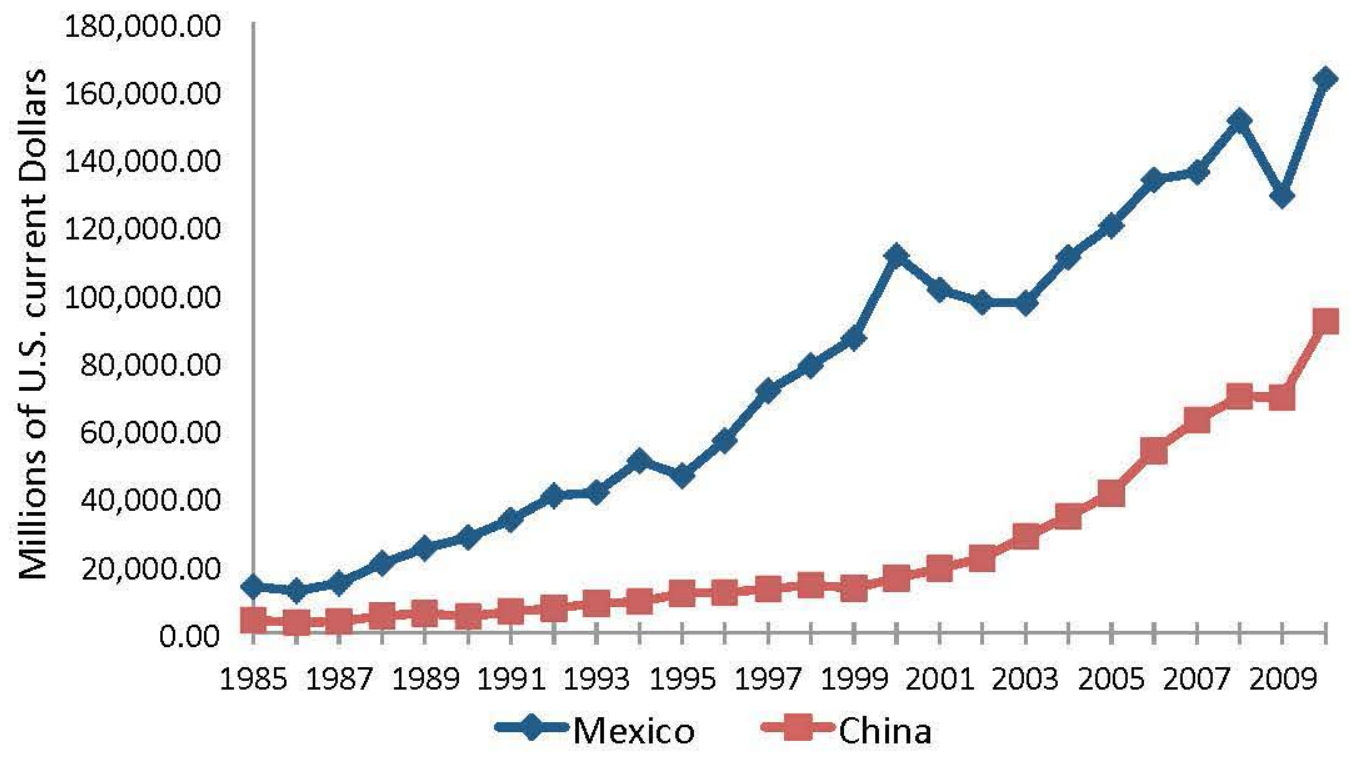


Iranzo and $\mathrm{Ma}$ (2006) conclude that the competitive effects of China have been detrimental for Mexico. NAFTA may have given Mexico one decade of a privileged position in the U.S. market, but with the opening of China to the world market, Mexico faces new competition. ${ }^{5}$ Their study examines the disaggregated sector data, based on commodities. Using the 4-digit industry code (SITC) they find a negative correlation between Mexico and China with respect to the U.S. market. Their analysis shows no statistical significance for the pre-NAFTA period but a statistically significant negative effect for the post-NAFTA period. Their results imply that the competitive effect is largely contained within existing products, for example the gradual displacement of previously traded Mexican-made Barbie dolls by Chinese ones (2006:16).

On the other hand, for some commodities such as flat-screen televisions, they find that China complements Mexico's exports to the United States. This product requires parts such as the glass component from China, but due to its large size, the specialized packing and assembly take place in Mexico (Iranzo and Ma 2006). Others, such as A.T. Kearney, voice a similar optimism, predicting that "Although Mexico competes with China for manufacturing investments, its proximity to U.S. markets will likely keep it competitive for investment in heavy goods, such as vehicles, transport equipment and large consumer durables" (2007: 18).

Figure 4. Ratio of Mexico to China in U.S. Imports of TV Receivers (SITC 761)

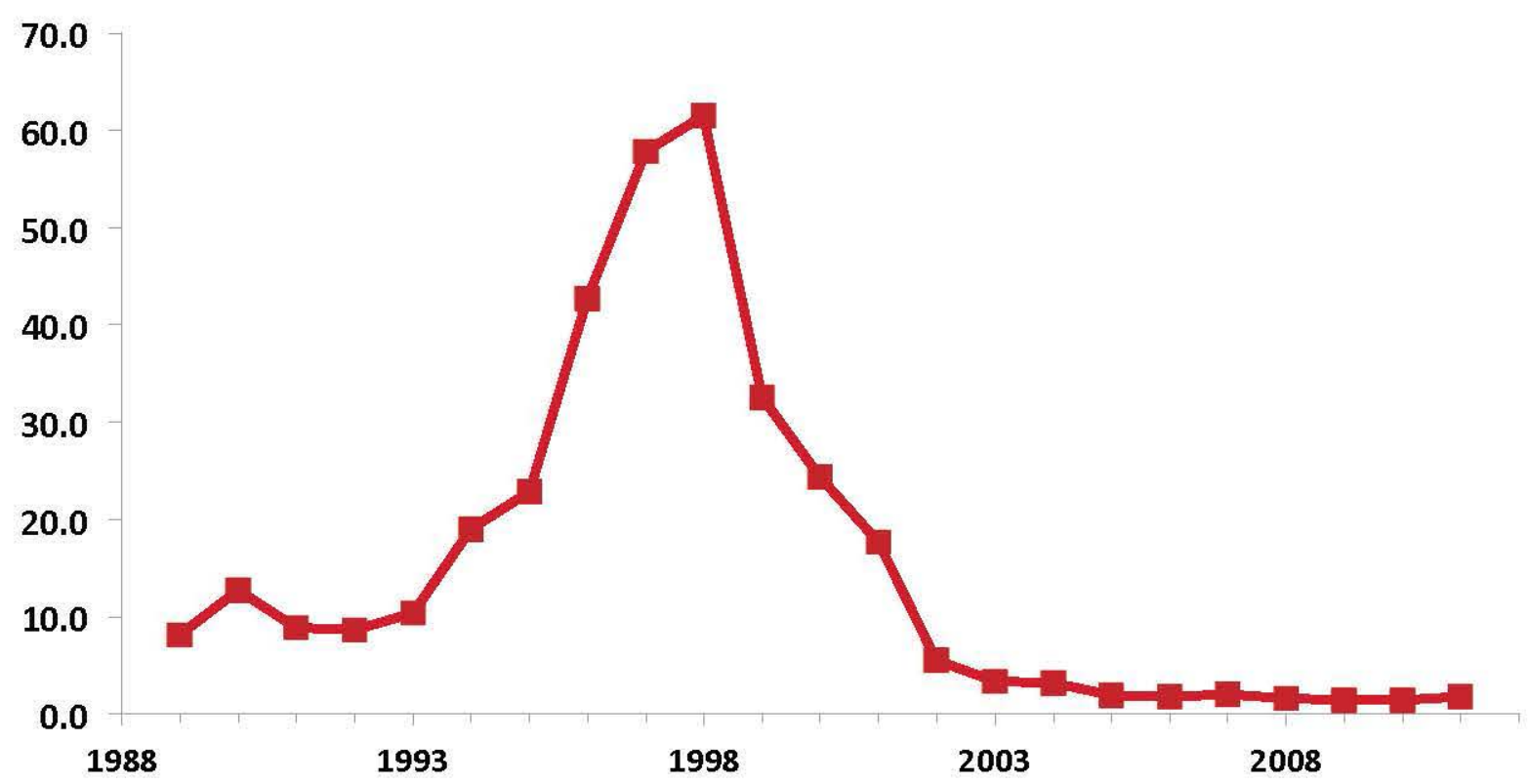

For other commodities, the data do not justify optimism. Consider the category of TV receivers, including video monitors \& projectors (U.S. Census Foreign Trade Standard International Trade Classification SITC 3-digit group \#761). In 1993, Mexico's share of the U.S. imports was 10.4 times greater than China's. In post-NAFTA 1996, U.S. imports from Mexico had risen to 42.7 times greater in dollar value than those from China (including transportation

\footnotetext{
${ }^{5}$ This diversion from Mexico to China repeats processes that unfolded elsewhere when Mexico joined NAFTA. Industries left the Dominican Republic for Mexico, for example.
} 
costs). Mexico's import dominance over China rose to a high of 61.5 times in 1998 before beginning a precipitous decline. By 2002 Mexico's import share had slipped to only 5.5 times that of China. By 2007, China and Mexico were about even (Figure 4) ${ }^{6}$.

The number of enterprises in the Mexican maquiladora sector dropped from a peak of 3,703 in December of 2000 to 3,230 in July 2003. Of the 523 enterprises that left during this period, one-third relocated to China, with the rest moving to other Asian countries, Central America, or the Caribbean (Werner, Barros, and Ursúa 2006). Carrillo and Gomis (2003) attribute Mexico's foreign investment losses to a number of additional factors. They point to improvements in the macro economy which strengthened the peso against the dollar and created a wage and production-cost push. Second, they suggest that Mexico is disadvantaged by the NAFTA rules that prevent a third country from using any one of the NAFTA signatories as a trampoline to get into the other two. They also point to the deterioration of Mexico's infrastructure and lack of resources for new investment in roads, ports, and telecommunications, resulting in increased delivery and distribution time. They and others (Hanson 2010) judge that poor public security and excessive bureaucratic hurdles also contribute to reduced enthusiasm for investment in Mexico.

\section{The China Factor in Mexican Garlic Trade}

Attentive to the fact that the fate of Mexico's exports vary by historical period, by destination, and by commodity, I turn to the question of Mexico's export market for garlic. Could Mexico be a country, and garlic a commodity immune from the perpetual race to the bottom? There are reasons for optimism. Mexico: rural, contiguous with the United States (particularly crucial for fresh perishable produce), and signatory to NAFTA, had comparative advantages when it came to garlic. In sampling garlic, I am choosing one commodity that should have been more successful in resisting the two processes associated with the U.S. economic decline (commodity chains and race-to-the-bottom). Rather than asking if the outcome described here is generalizable to commodities beyond garlic I invert the question to ask if observed negative outcomes for labor-intensive industries such as textiles, shoes, toys \& electronics are generalizable to agricultural commodities that should have been immune. Unfortunately, the answer is yes. However, the consequences for Mexico may not necessarily be repeated in other semi-peripheral and/or peripheral countries. While these countries share similar levels of poverty, inequality, and stagnation, they are not all alike in terms of their dependency status. Historically, Mexico has had a dependent relationship with the United States.

In 1991, the United States imported garlic from Argentina and Mexico (19 and 57 percent of imports respectively) to supplement the domestic supply during the off-season. As the U.S. demand rose from .4 lbs. per capita in 1970 to $2.5 \mathrm{lbs}$. in 2009 , it was met by increased production and increased imports, with the latter growing more quickly. The United States is now the world's largest import market for fresh garlic, followed by Indonesia, France, and Brazil (FAO). By 2010, 54 percent of the available U.S. supply was imported; up from 11 percent in $1980 .{ }^{7}$ In 2004, imports were comprised of fresh (76\%), dried garlic flakes $(15 \%)$, and powder (9\%). As suggested above, a large proportion of garlic imports came from Mexico, which had the comparative advantages of good quality and low transportation costs. Importing and contract

\footnotetext{
${ }^{6}$ My calculations

${ }^{7}$ Some of the available U.S. supply was exported. In 2006, it was 6.4 percent.
} 
growing were two mechanisms of acquiring Mexican garlic. The trade agreements of GATT (1986) and NAFTA (1994) further enhanced Mexico's access to the U.S. market.

The United States now imports garlic from China, the global leader in garlic production and exports. China's competitiveness grew following its 2002 accession to the WTO; since then it has dominated U.S. garlic imports. This had grave implications for Mexico. In 1980, China and Mexico exported about equal quantities globally (14011 and 13758 tons respectively). By 2009 , China's global export volume was 126 times that of Mexico's. Mexico's share of the value of U.S. total garlic imports dropped from 50 percent in 1990-92 to 16 percent in 2004-06, and Argentina's dropped from 23 to 9 percent (Huang and Huang 2007). As with textiles and electronics, despite the geographic advantage, Mexico lost to Chinese competition. Price was the determining factor. In the Los Angeles market in June 2013, for example, white garlic from China and Mexico sold for \$2.28/kilo and \$4.4/kilo, respectively (Mexico 2013).

U.S. purchase of Mexican garlic was inversely related to that from China (Figure 5). As a consequence of a 1993 antidumping petition filed (with the USITC) by U.S. Fresh Garlic Producers Association (FGPA) against China, a 377 percent tariff was placed on 159 Chinese garlic shippers and traders. This tariff was judged to be equal to the Chinese dumping margin. Importers were required to post a bond or cash deposit equal to 377 percent of the invoice value (59 FR 59209 1994). During this period, Mexico recaptured some of the U.S. market. However loopholes in the legislation eventually resulted in China retaking the lead. In 2002, for the first time, U.S. garlic imports from China surpassed those from Mexico. By 2012, 88 percent of U.S. imported garlic was supplied by China and only 8 percent by Mexico.

Figure 5. U.S. Imported Garlic Market Shares: Mexico and China

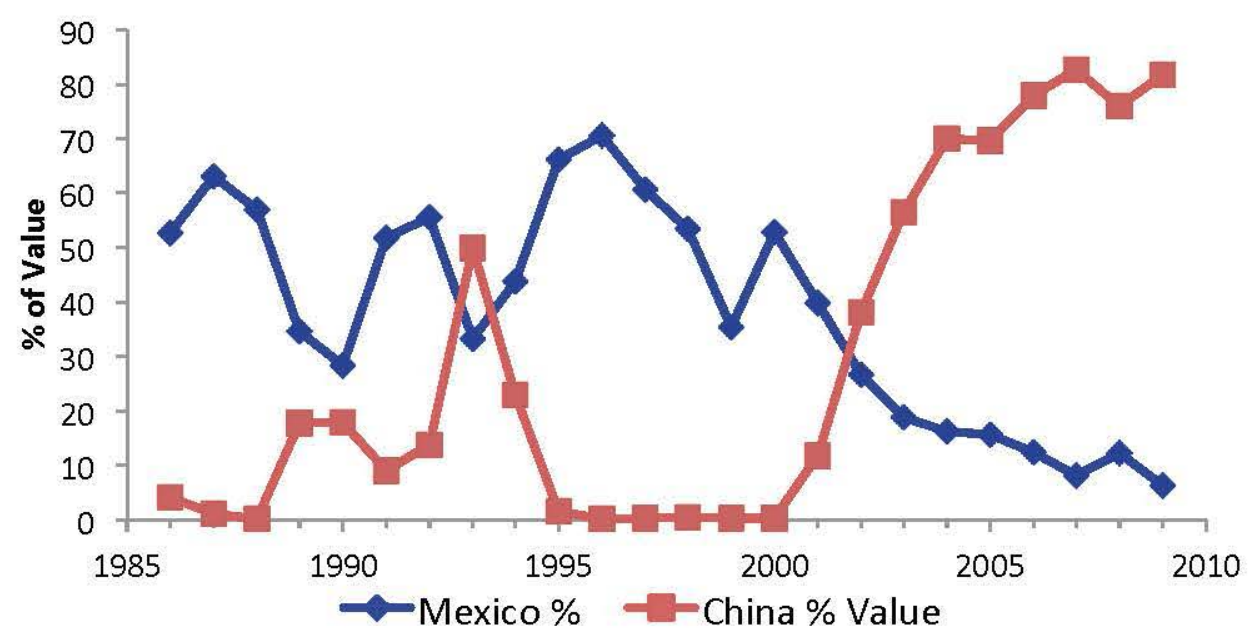

The fresh garlic market was particularly important since an average of 94 percent of Mexican garlic exports were fresh. By 2012, 67 percent of the U.S. supply of fresh and chilled garlic was imported and 90 percent came from China. Mexico was losing the U.S. market. In 2000, 95 percent of Mexican exported garlic was destined to the United States; by 2009, it had dropped to 63 percent. Overall the average percentage of Mexican production that was exported 
fell from 28 percent (1980-2001) to 24 percent (2002-2010). In short, a smaller percentage of Mexico's production was exported and its production declined (Table 5).

Table 5. Mexico's Declining Garlic Industry

1980-2001 Average 2002-2010 Average

\begin{tabular}{lll}
\hline $\begin{array}{l}\text { Quantity Exported (Tonnes) } \\
\text { Production Exported } \\
\text { (percent) }\end{array}$ & 15219 & 11448 \\
$\begin{array}{l}\text { Exported destined for U.S. } \\
\text { (Percent) }\end{array}$ & $95 \%(20 \%)$ & $63 \%(2009)$ \\
$\begin{array}{l}\text { Produced (Tonnes) } \\
\begin{array}{l}\text { Available garlic imported } \\
\text { (Percent) }\end{array}\end{array}$ & 54276 & 48311 \\
\hline
\end{tabular}

\section{The Real South-South Competition}

Garlic arrived in Cuba with the Spanish conquerors and was subsequently planted in Mexico by Cortez. Planting expanded along with domestic consumption. Currently about 65 percent of the production is consumed locally as fresh garlic, and around 10 percent is used in processed forms (SAGARPA 2010). Mexican producers began losing some of their own domestic market to imported garlic. The share of imported garlic in Mexico's national supply reached a high of 40 percent in 2002, but the averages for the 1980-2001 and 2002-2010 periods were 6.4 percent and 31.4 percent respectively. A first wave of imports came from the United States, followed by Chile and then Argentina. The commercial producers and distributors' organization, Comité Nacional Sistema Producto Ajo (CONAJO), complained that garlic was coming into Mexico from Chile and Argentina, even though production in those countries was down. CONAJO alleged that imports from China had arrived illegally through the southern and northern borders of Mexico. Producers were at a great disadvantage because of China's greater volume and lower prices. Cases of Chinese garlic triangulation through Chile were documented. Illegal imports were facilitated by free trade agreements that Mexico had signed with Chile (Chile-Mexico, effective 1998) and Argentina (Mexico-Mercosur, effective 2006). Mexican producers criticized the low labor standards and poor phytosanitary conditions of Chinese garlic production. CONAJO's complaints resulted in a July 26, 2007 Decree (Art. 73) which imposed a prison sentence and a fine on offending commercial importers.

In 2008, a parliamentary group of the PRD (Party of the Democratic Revolution) testified to the Mexican Senate that Chinese garlic was still causing financial injury to Mexican producers who had invested resources and were using the best agricultural practices and technology in order to offer consumers a product high in quality, freshness, and cleanliness. Producers complained about the high volume of imports in the 2008-2009 period. In 2009, twenty-three charges involving 8.5 tons of garlic were filed against importers in thirteen Mexican states. Additional imports could not be definitively identified because they were mixed with garlic from other origins. Two importing companies had their stock destroyed (SAGARPA 2009).

In 2011, Mexico signed a Free Trade Agreement with Peru (effective February 1, 2012). CONAJO argued unsuccessfully against the Government's "arbitrary" decision to embark on the FTA on four grounds (CONAJO 2011). First, Peru's very low levels of sanitation: fields littered 
with garbage, and human and animal defecation in water sources used for irrigation. Second, lower production costs because wages are about 30-40 percent below Mexican salaries and cheap water is available from the Andean run off. Third, imports damage a Mexican sector that over decades has invested millions of pesos in the production of the highest quality garlic. Fourth, Peru imports garlic from China that will flood the Mexican market. The statement from the president of CONAJO ended with the warning that if the garlic industry could no longer employ workers, they will be forced to migrate to the United States generating the "consequent and known problems of family disintegration, desertion, and etc." The PRD parliamentary group requested a renegotiation of the Mexico-Peru FTA in order to award garlic a 5-year exclusion. The Secretary of the Economy rejected it (Mexico SE 2011).

For Mexico, this South-South competition and the loss of both the U.S. and Mexican markets led to reduced production and even destruction of crops. While not the largest producer in Mexico, the state of Baja exports close to 100 percent of its crop. Garlic production began increasing in 1993 and peaked in 1998-1999. Since then it has been declining. The number of farmed hectares dropped from 609 in 1998-1999 to 394 in 2003-2004. Producers in other states were destroying their crop. In 2012, 60 percent of garlic production in Zacatecas (the largest producer in Mexico) remained unsold in storage. In 2013, some 400 producers in Tlacolula, (Oaxaca) tossed 200 tons of garlic for lack of a market. They complained of inadequate transportation, intermediaries (coyotes) who claimed too much of the profits, and extremely low prices (CONAJO 2013). In summary: garlic production was down; exports were down; and exports to the United States were down. Garlic sales are not a major driver of Mexico's GDP, but even this small sector with its comparative advantages was not immune to the deleterious effects of the race-to-the-bottom.

\section{Food and Markets that Matter}

While researchers have identified the Chinese-Mexican competition in commodities ranging from t-shirts to electronics, it also exists for agricultural commodities. The U.S. food supply is basically ome grown but increasingly comes from other countries. In 2011, between 10 and 15 percent of food consumed in the United States was imported. For fruits and vegetables, the imported share of consumption rose from 9.5 (1977-1979) to 20.1 percent in 1999 (USDA). Some of the demand is for traditionally consumed foods not produced in the United States (e.g. bananas) or produced only seasonally (many fruits). Additional import demand comes from new migratory streams that prefer foods from their country of origin. Other foods are imported because they can be produced less expensively abroad and/or are given tariff advantages. Del Monte, for example, moved its asparagus production from the state of Washington to Peru following the 1991Andean Trade Preference Act (ATPA) (VGN 2007; Egan 2004).

For all these cases, the U.S. food market should be secure for Mexican exporters. Geography has traditionally played a major role in the global trade patterns of fresh produce that is highly perishable and seasonal (Huang and Huang 2007). In 2010, 80 percent of all Mexico's exports were destined for the United States. Although agricultural, fish, and food products made up only 18 percent of total exports, 77 percent of those exported commodities went to the United States. For exported vegetables, 95 percent were destined for the United States. And for the United States, about 50 percent of total imported vegetables came from Mexico (in 2011, though this figure was more or less stable over the previous years). 
But even Mexican agricultural exports have encountered serious competition in the last decades. China is one of the fastest growing sources of U.S. food imports, more than tripling in value between 2001 and 2008. In 2008, in response to this increase, the FDA opened its first overseas office in China (Gale and Buzby 2009). In higher value-added imports such as dried or preserved vegetables, China's U.S. market share rose from 15.6 percent in 2000 to 33.1 in 2011. In contrast, Mexico's share dropped from 11.3 to 6.6 percent. These statistics reflect China's comparative advantage over Mexico--lower labor costs. Costs are so low that some fish, poultry, berries, and other products are shipped to China, processed in factories along the Chinese coast, and re-exported (Sanchez, Franke, and Zecha 2008). China may also have an advantage in more advanced food processing technology. Twenty one of the 32 Mexican states produce garlic. Although Zacatecas leads in production, with somewhere over 50 percent destined for export, it has only one firm dedicated to transforming garlic into value-added products (SAGARPA 2010).

The globalization of garlic follows the road already taken by other commodities. Globalization is more appropriately characterized as South-South competition (S-S), and S-S as a race to the bottom. This trend was pronounced in apparel, perhaps a pioneer in overseas sweatshops. Some U.S. producers (who weren't part of an earlier wave of outsourcing to Asia) journeyed from the United States to Mexico, then to China, and then from China to Vietnam or Bangladesh. Chan and Ross illustrate how the offshoring of the labor-intensive apparel industry pits countries of the South against one another (2003:1011). Numerous researchers have identified Chinese-Mexican competition in commodities ranging from t-shirts to electronics (Carrillo and Gomis 2003; Chan and Ross 2003; Iranzo and Ma 2006; Rumbauth and Blancher 2004). In general, new trade developments, such as China's adherence to the WTO, can unleash a move of trade and capital. Improving wage scales in any of the South economies may do the same. As Mexican wages crept up, it lost foreign investment and markets to China. This highlights the dilemma for developing nations: they cannot all be net exporters and use the export-led strategy as their motor of development.

\section{Semi peripheral Nations Embedded in Global Commodity Chains}

The story of Mexico and China is more multifaceted than a race to the bottom. China's export and foreign investment gains alongside Mexico's losses are not simply the result of two nations acting independently. They are connected by virtue of their commercial interactions with the United States. Thus the reformulated question is: "What is the fate of nations such as Mexico that are dependent upon another nation which is losing its global dominance?" Andre Gunder Frank argued that "the satellites experience their greatest economic development and especially their most classically capitalist industrial development if and when their ties to their metropolis are weakest" (1969:10). Inversely, he argued, as core countries experienced crises of war or depression (such as the Napoleonic Wars, WWI, and WWII), the loosening of trade and investment ties allowed satellites to initiate autonomous industrialization and growth.

In the post-WWII period, the United States enjoyed global hegemony, a position supported by its superiority in production. As the United States began its hegemonic slide in the 1970 s, it embarked on numerous attempts to ameliorate its profit crises. One was offshoring. The early maquiladora programs offered a buffer against consumer volatility and low-wage labor that helped to ameliorate this crisis. NAFTA opened Mexico further to trade and capital flows. Some of the research described in this article suggests that Mexico's access to the U.S. market increased for a few years post-NAFTA. But the dual symptoms of the U.S. hegemonic decline- 
weakening consumer demand and use of emerging markets for offshoring - had negative consequences for Mexico: it lost the race to the bottom.

Following Frank, the U.S. economic slide should have boded well for Mexico, but it appears that Mexico is unlikely to substantiate his prediction. There are several reasons why his observations about Latin America may not work for Mexico. The current phase of globalization no longer looks like those described by Frank, where dependent nations regained control of preexisting domestic markets in the absence of imported foreign commodities. This is because Mexico's economy has been integrated into the contemporary global economy as one node in a commodity chain. Mexico will have a difficult time returning to autonomous industrialization and growth because the contemporary patterns of hosting part of a GCC often occur without significant technology transfers (Castells 1989). This is connected to a second obstacle. Mexico's historic dependence on the United States led it to accept neoliberal reforms, which included amendments to the Mexican constitution. Mexican governments transformed three major arenas: they furthered opened trade relations with the world; terminated government-directed development programs; and significantly reduced state involvement in production, capital accumulation, income redistribution, and social welfare. These reforms were strongly encouraged by the IMF and the World Bank following Mexico's 1982 debt crisis and subsequent debt restructuring. They destabilized the autonomous development that had bourgeoned under the earlier Import Substitution Industrialization (ISI) model. Because of Mexico's preexisting dependency and periodic economic stagnation, it attempted to stimulate growth by accepting what can be characterized as further dependency. Trade dependency was augmented by foreign direct investment and debt dependency, which in turn was augmented by foreign portfolio investment dependency. Mexico also depended on the United States as an escape valve for a growing population which its labor market was incapable of absorbing.

The fate of Mexico seems more aptly described by the Mexican lament: "cuando EUA estornuda, México sufre pulmonía" [when the United States sneezes, Mexico catches pneumonia]. As Faux (2009) opines, "If Mexico could not prosper during fifteen years of exporting goods and people to a bloated U.S. consumer market, it is hard to believe it will be able to do so when that market has slimmed down." Emerging market hospitality to core offshoring was not guaranteed as one hegemon gave way to another. Capital has no loyalty: not to its country-of-origin and much less to a country-of-destination. The foreign investment confidence rankings index produced by A.T. Kearney communicate investors' high confidence in China and their wavering and declining opinions about Mexico. By 2002, China had taken the number one position in the Confidence Index. In 2012, Mexico did not even make the top twenty-five, though it did return to the list in 2014.

\section{Conclusion}

What are the conditions that allow an export-processing platform--just one weak link in a longer and more concentrated GCC--to accumulate enough surplus to jump-start its economy? Leaving aside the debate regarding China's potential for hegemonic status, it is taking on many functions typically attributed to hegemons. China is reinforcing the dependency of other underdeveloped nations: it imports raw materials from Africa and Latin America, exports finished goods to them, and employs strategies of foreign direct investment. In addition to the classic WS-T notion of exchanges, it now (like the United States) dominates some global agricultural markets. 
Will China follow Mexico's trajectory and lose its comparative advantages as capital moves on to Vietnam, Bangladesh, or Africa? Its political regime differs from Mexico in significant ways. China is not subject to the same international pressure to implement neoliberal reforms. In this way, China has a greater chance of capturing savings from its export-processing platforms and investing in ways that might promote growth. And China has yet to forsake all SOEs (state owned enterprises), which may also be contributing to Chinese primitive capital accumulation.

Many maintain that globalization of trade is the most efficient economic system. Vertical integration and/or comparative advantages are justifications for this verdict. But even granting the efficiency argument, which has a good number of critiques (Greenberg 2014), there must be a concern for the 'externalities' created by the South-South competition/ race to the bottom. These include sustainability of any given economy, as well as of the environment, along with the fate of citizens and workers. Surely CONAJO was being polemical in 2011 when it argued to the Mexican Senate that if garlic wasn't protected in the Mexico-Peru free trade agreement, Mexico would risk more citizens fleeing to the United States. This is where externalities of economic theory "become the social problems of nations and the tragedies of individuals" (Schwartzman 2013).

\section{References}

ATKearney. 2014. "Ready for Takeoff."

http://www.atkearney.com/documents/10192/4572735/Ready+for+Takeoff++FDICI+2014.pdf/e921968a-5bfe-4860-ac51-10ec5c396e95.

. 2012. "Cautious Investors Feed a Tentative Recovery."

http://www.atkearney.com/index.php/Publications/foreign-direct-investment-confidenceindex.html. . 2010. "Investing in a Rebound".

http://www.atkearney.com/documents/10192/525de83b-100a-43c2-a603-2793ce7c6d00. . 2007. "New Concerns in an Uncertain World."

http://www.atkearney.com/index.php/Publications/foreign-direct-investment-confidenceindex.html.

Bair, Jennifer. 2005. "Global Capitalism and Commodity Chains: Looking Back, Going Forward." Competition \& Change 9, no. 2, (June):153-180.

Bonanno, Allesandro and Josefa Salete Barbosa Cavalcanti. 2011. "Introduction in Globalization and the Time-Space Reorganization: Capital Mobility in Agriculture and Food in the Americas." Research in Rural Sociology and Development 17: 1-31.

Samuel Bowles, David Gordon, and Thomas Weisskopf. 1983. Beyond the Wasteland. Garden City, New York: Anchor Press

The Brasilians. 2008. "China's Numbers in Latin America a Concern for Brazilian Steel Industry." November. NY: The Brasilians Press, Inc.Carrillo, Jorge and Redi Gomis. 2003. "Los retos de las maquiladoras ante la perdida de competitividad." Comercio Exterior Magazine 53, no. 4 (April):318-327. http://revistas.bancomext.gob.mx/rce/magazines/19/3/Carrillo3741.pdf . 
Castells Manuel and Roberto Laserna. 1989. 'The New Dependency: Technological Change and Socioeconomic Restructuring in Latin America.' Sociological Forum 4, no. 4 (Dec.): $535-$ 560. http://www.jstor.org/stable/684424.

Chan, Anita and Robert J. S. Ross. 2003. "Racing to the bottom: international trade without a social clause." Third World Quarterly 24, no. 6:1011-1028.

Comite Nacional Sistema Producto Ajo, A.C (CONAJO). 2013. "A la basura, 200 tons de ajo por falta de Mercado." Noticias April. http://www.conajo.com.mx/Noticias/News/.

2011. "Sector Del Ajo Afectado Por Firma De Acuerdo De Integración Comercial Entre México Y Perú." www.noticiasguanajuato.com.mx/portadaAjo.html.

Economist. 2013. "When giants slow down.' July 27.

Egan, Timothy. 2004. "War on Peruvian Drugs Takes a Victim: U.S. Asparagus." New York Times. April 25. http://www.nytimes.com/2004/04/25/national/25ASPA.html.

Enciso. Angélica. 2013. "En pobreza, 45.5\% de la población mexicana: Coneval." La Jornada, July 29. http://www.lajornadadeoriente.com.mx/2013/07/29/en-pobreza-45-5-de-lapoblacion-mexicana-coneval/.

FAO. http://faostat.fao.org/site/567/DesktopDefault.aspx?PageID=567\#ancor.

Faux, Jeff. 2009. "So Far From God, So Close to Wall St." The Nation. www.thenation.com/ July 15 .

Frank, A. Gunder. 1969. "Latin America: Underdevelopment or Revolution." New York: Modern Reader.

Gale, Fred, and Jean C. Buzby. 2009. "Imports from China and Food Safety Issues." Economic Information Bulletin No. 52, U.S. Department of Agriculture, Economic Research Service, July. http://www.ers.usda.gov/publications/eib52/eib52.pdf.

Gallagher, Kevin P. and Roberto Porzecanski. 2008. "China Matters: China's Economic Impact in Latin America." Latin America Research Review 43, no. 1: 185-200.

Gary Gereffi, John Humphrey, Raphael Kaplinsky, and Timothy J. Sturgeon. 2001. Globalisation, Value Chains and Development, IDS Bulletin 32 no. 3 (July):1-8. http://www.ids.ac.uk/files/dmfile/gereffietal323.pdf.

Gereffi, Gary and Miguel Korzeniewicz. 1994. Commodity Chains and Global Capitalism. Westport, CT: Praeger.

Gilllman. The Charles E. Gillman Company. www.gillman.com.

Greenberg, Paul. 2014. "Why Are We Importing Our Own Fish?" New York Times, June 20.

Hanson, Gordon H. 2010. "Why isn't Mexico Rich?" Journal of Economic Literature 48, no. 4 (December):987-1004. http://www.nber.org/papers/w16470.

Harvey, David. 2007. "Neoliberalism as Creative Destruction." Annals. AAPSS 610, (March):21-45.

Hough, Phillip A. 2012. A Race to the Bottom? Globalization, Labor Repression, and Development by Dispossession in Latin America's Banana Industry. Global Labour Journal 3, no. 2 (September):237-262.

Hopkins, T. and Wallerstein, I. 1977. Patterns of development of the modern world-system. Review 1(2), pp. 11-145.

Huang, Sophia and Kuo Huang. 2007. "Increased U.S. Imports of Fresh Fruit and Vegetables." FTS-328-01.

ERS. www.ers.usda.gov/Publications/fts/2007/08Aug/fts32801/fts32801.pdf. 
Husted, Steven and Shuichiro Nishioka. 2013. "China's fare share? The growth of Chinese exports in world trade." Review of World Economics / Weltwirtschaftliches Archiv 149, no. 3:565-585.

Iranzo, Susana and Alyson C. Ma. 2006. "The Effect of China on Mexico-U.S. Trade: Undoing NAFTA?" www.sandiego.edu/peacestudies/documents/tbi/iranzo ma TBI.pdf.

Jenkins, Rhys, Enrique Dussel Peters, and Mauricio Mesquita Moreira. 2008. "The Impact of China on Latin America and the Caribbean." World Development 36, no. 2:235-253.

Mexico. Secretary of Economy (SE). 2011. "Oficio No. DGG.-585/2011." http://sil.gobernacion.gob.mx/Archivos/Documentos/2011/08/asun 2787069 20110817 13 13589152.pdf.

Mexico. Secretariat of Agriculture, Livestock, Rural Development, Fisheries and Food (SAGARPA). 2009. "Problemática del Ajo en México durante 2009." http://www.sagarpa.gob.mx/Delegaciones/guanajuato/Lists/Boletines/DispForm.aspx?ID=1 9.

Rumbaugh, Thomas and Nicolas Blancher. 2004. "China: International Trade and WTO Accession." W W Working Paper, WP/04/36. www.imf.org/external/pubs/ft/wp/2004/wp0436.pdf.

Sanchez, Jorge, Tanya C. Franke, and Amy Zecha. 2008. "U.S. Seafood Exports to China are Re-Exported to Third Countries" GAIN Report No. CH8005, U.S. Department of Agriculture, Foreign Agricultural Service, January. www.fas.usda.gov/gainfi les/200808/146295431.pdf.

Schwartzman, Kathleen C. 2013. The Chicken Trail: Following Workers, Migrants, and Corporations across the Americas. Ithaca: Cornell University Press.

Thurow, Lester. 1992. The Coming Economic Battle among Japan, Europe, and America. New York: William Morrow \& Company.

United Nations. UN Comtrade data.

http://comtrade.un.org/db/dqBasicQueryResults.aspx?px $=\mathrm{S} 3 \& \mathrm{cc}=761,7611,7612 \& \mathrm{r}=842$ $\& \mathrm{p}=484 \& \mathrm{rg}=1 \& \mathrm{y}=1996 \& \mathrm{so}=8$.

U.S. Department of Agriculture (USDA). "Quantity of U.S. food imports." www.fas.usda.gov/gats.

U.S. Department of Commerce, Bureau of the Census, Foreign Trade Division. http:/Www.census.gov/foreign-trade/balance/c5700.html.

World Trade Organization

http://stat.wto.org/StatisticalProgram/WSDBViewData.aspx?Language=E.

(WTO).

Weik, Juan. 2013. "Interview: China's share in Brazilian anti-dumping cases set to increase."

First,

June

17. http:/www.kslaw.com/imageserver/KSPublic/library/publication/2013articles/6-1713 Dorn Steel First.pdf.

Werner, A, R. Barros, and J. Ursúa. 2006. "The Mexican Economy: Transformation and challenges." In Changing Structure of Mexico: Political, Social, and Economic Perspectives. Edited by Randall, $2^{\text {nd }}$ Edition. London: M.E. Sharp. 